\title{
Histone H2A Gene
}

National Cancer Institute

\section{Source}

National Cancer Institute. Histone H2A Gene. NCI Thesaurus. Code C154299.

A gene encoding the core histone protein histone H2A. 